\title{
POR UM DIREITO MENOS AFETIVO
}

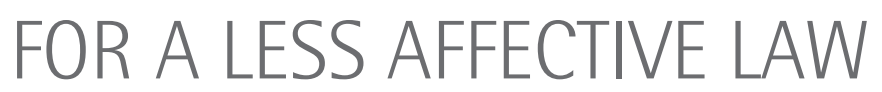

\author{
Luciana Poli \\ lucostapoli@yahoo.com.br
}

Recebido em: 09/06/2016

Aprovado em: 20/10/2016

Sumário: 1. Introdução. 2. A análise do discurso em Foucault. 3. A insuficiência do afeto como elemento caracterizador da família. 4. Da subjetividade em massa à subjetividade emergente. 5 . Família: núcleo de cooperação. 6. Conclusão. Referências.

\section{Resumo:}

O estudo se propóe a analisar o papel preponderante que o afeto tem representado no discurso jurídico como elemento legitimador de núcleos familiares. O objetivo do trabalho é apontar de forma crítica a escolha desse elemento e suas repercussóes políticas e subjetivas. A análise aponta que a legislação tem acomodado sob o manto da proteção judicial modelos de afeto, ao invés de garantir o direito democrático de escolha da família de cada um pautado em motivos diversos, que não apenas no discurso do amor romântico que acaba por produzir um quadro regulamentar para as subjetividades.

\section{Palavras chave:}

Afeto; família; subjetividade.

\section{Abstract:}

The study aims to analyze the important role that the affection is represented in legal discourse as legitimizing element of households. The target is to point out critically the choice of this element and its political and subjective impact. The analysis shows that the legislation has accommodated under the cloak of judicial protection affection models, instead of guaranteeing the democratic right to choose the family of each ruled by various reasons, not only in romantic love speech that it produces a regulatory framework for subjectivities .

\section{Keywords:}

Affection ; family; subjectivity. 


\section{Introdução}

A compreensão e aceitação das múltiplas dimensões que pode assumir a família se perfilham como uma das muitas inquietaçóes que assombram as ciências sociais contemporâneas.

Considerando a relevância que o afeto ${ }^{1}$ tem assumido recentemente na configuração dos núcleos familiares, na discussão acerca da possibilidade ou não de se atribuir responsabilidade civil, na sua ausência, às relaçóes paterno-filais e, ainda, considerandose os fundamentos que nortearam as decisóes do STF na ADPF 132 e ADI $4277^{2}$ que conferiram efeitos jurídicos às unióes estáveis constituídas por pessoas do mesmo sexo, torna-se necessário investigar as formas e sentidos que o direito tem conferido à afetividade de modo a questionar sua relevância para o direito de família e a possibilidade de funcionar como elemento justificador das formas de família.

A análise proposta será apresentada considerando-se a obra de Foucault, sob a análise do discurso crítico, considerando que a afetividade como elemento caracterizador das unióes familiares ganhou destaque com a difusão do termo homoafetividade ${ }^{3}$. Percebe-se que entre os juristas a noção de homoafetividade ${ }^{4}$ disseminou-se sem quaisquer questionamentos. Como se, imbuídos de conhecimentos interdisciplinares inatos pudessem os operadores do direito, atribuir um sentido único ao(s) afeto(s) e sobre o conteúdo das relaçóes conjugais. Nesse diapasão, o afeto emerge no campo jurídico como um modelo universal, um "standard" apto a construir um ideal normativo. Como se todas as experiências conjugais e paterno-filiais pudessem ser aprisionadas ou amoldadas em um determinado padrão.

A CR/88 possibilitou uma visão pluridimensional da família, consolidando a ruptura com o passado objetificado intolerante, hierarquizado e preconceituoso da família até então existente apenas se moldurada no modelo normativo para um modo de ser em família. Com essa linguagem nos afastamos do conceito dogmático e ultrapassamos as discussóes acerca da natureza da família para compreendermos a família não como um comportamento, um modo de agir normatizado, mas como um movimento básico da existência humana (CAMARGO, 2001, p. 30), que pode direcionar-se em múltiplos sentidos e para incontáveis objetivos. Ao compreendermos a família como algo além de um modelo comportamental pré-estabelecido ou desejado como ideal, mas como um modo de agir que toma espectros diversos, é possível compreender que a família não se sujeitará à normatização, já que será impossível ao legislador ou ao jurista prever ou tentar estabelecer todos os jeitos de ser em família.

A metodologia adotada será a análise crítica da doutrina e da jurisprudência a respeito da apropriação do conceito de afeto e suas repercussóes no direito de família.

\footnotetext{
No texto, as críticas referentes ao termo afeto consideram apenas o sentido romântico, de amor, como apropriado pelo discurso jurídico.

$2 \quad$ Nesses julgamentos, o STF reconhece como familia, merecedora de toda a proteção do Estado, a união estável entre pessoas do mesmo sexo. Embora a decisão represente grande avanço contra o preconceito, as justificativas da decisão merecem análise.

3 Atribuído à Maria Berenice Dias ao defender que não seria possivel falar em homossexualidade sem falar em afeto, já que, na sua concepção, as uniões de pessoas do mesmo sexo nada mais são do que vínculos de afetividade (DIAS, 2000, p. 1-26).

$4 \quad$ Não encontramos na doutrina estrangeira alusão ao termo homoafetividade, o que sugere uma terminologia eminentemente brasileira utilizada inclusive em documentos oficiais para designar as relações entre pessoas do mesmo sexo, pretendendo-se, assim, legitimar direitos através da afirmação jurídica da existência de um sentimento valorado como positivo.
} 


\section{A análise do discurso em Foucault}

$\mathrm{Na}$ abordagem de Foucault dos saberes, são compreendidos como produto dos regimes de verdade, os quais se referem à forma como um enunciado torna-se legítimo, adquire efeito e se estrutura no interior de um regime de verdade:

Cada sociedade tem seu regime de verdade, sua política geral da verdade: ou seja, os tipos de discursos que ela acolhe e faz funcionar como verdadeiros; os mecanismos e as instâncias que permitem distinguir os enunciados verdadeiros e falsos, a maneira como se sancionam esses e aqueles; as técnicas e os procedimentos que são valorizados para a obtenção de uma verdade; o estatuto daqueles que são encarregados de dizer aquilo que funciona como verdade. (FOUCAULT, 1994, p. 158)

O objetivo do analista do discurso é, portanto, descrever a estrutura dos diferentes regimes, isto é, as regras do que pode e do que não pode ser dito e do que é considerado verdadeiro. Assim, embora tenhamos, em princípio, um número infinito de maneiras de formular enunciados, o ponto de partida desta análise são as afirmaçóes que se apresentam de forma semelhante, recorrentes e associadas a um determinado regime de verdade, no interior do qual fazem sentido.

A estratégia perseguida pelo direito de família, ao apropriar-se do enunciado do afeto e evocar o amor romântico como modo de legitimação e justificação de direitos, contraria frontalmente o alerta de Foucault quanto aos riscos das formas de reconhecimento e seu aprisionamento potencial. Esse discurso abafa individualidades e ignora que as identidades brotam de enunciados produzidos e oferecidos por determinada cultura que reproduzem um campo delimitado do possível à experiência de si:

Essa forma de poder que se exerce sobre a vida cotidiana imediata, que classifica os indivíduos em categorias, que os designa por sua individualidade própria, que os ata à sua identidade, os impóe uma lei (regime) de verdade que deve ser reconhecida por eles e que os outros devem reconhecer neles [...] um sujeito atado a sua própria identidade pela consciência e conhecimento de si (FOUCAULT, 1994c, p. 227).

\section{A insuficiência do afeto como elemento caracterizador da família}

Ao que parece, o afeto como elemento conformador da família está na moda. Estar inserido e ser reconhecido como parte de um núcleo familiar essencialmente afetivo é o rótulo que todos aparentam desejar. No entanto, o afeto na seara jurídica tem sido normalmente encarado de forma superficial, como um sentimento único, uma etiqueta de convivência, como uma qualidade ou um valor positivo que se busca alcançar. É visto como um produto do bem, um objeto de consumo indispensável à configuração do núcleo familiar. Romanticamente é visto como a salvação do indivíduo dos efeitos nefastos da vida em sociedade na contemporaneidade.

Essa visão inocente e singela do afeto serve à superficialidade do homem contemporâneo e apazigua a busca por soluçóes jurídicas diante da complexidade das relaçóes familiares. Ora, a questão da afetividade deve, porém, ser analisada cum grano 
salis. É tempo de apresentar um enfrentamento crítico da visão romântica da família, fundada no amor e no afeto. A família tem sido apresentada tão somente como o locus do afeto, o ambiente mais adequado para a promoção do ser humano. De fato, a família ainda é, como regra, o ambiente mais adequado para o desenvolvimento do ser humano, mas não por ser necessariamente um local de amor e de afeto. Dentre outras razóes, é por ser o ambiente em que nascemos e no qual nos sentimos naturalmente mais protegidos. Seguramente, há amor e afeto no âmbito familiar, mas não só; há também ódio, rivalidades e violência (física e moral).

É importante frisar tudo isso, porque, há notícia de alguns magistrados, com base nessa visão romântica e irreal de família, como o locus do afeto, que inserem crianças em lares adotivos, sem uma pesquisa adequada, a fim de se constatar se os adotantes têm, realmente, condiçôes de criar filhos. Eventualmente, esse romantismo piegas pode levar um juiz a inserir uma criança num lar de psicóticos perigosos, que só farão projetar suas perversóes no pobre filho adotivo. Melhor será deixá-lo no orfanato, por pior que seja. Família não é apenas locus de amor e afeto. Família é um agrupamento de seres humanos reais, neuróticos quando nada, que se amam, mas se odeiam, que se fazem bem, mas se fazem mal. Família é locus de amor, mas também de violência e de desafeto. Essa é a família da vida real. A se falar em família como locus de afeto, só pode ser no sentido psicanalítico, não no sentido vulgar.

Para a psicanálise, afeto é um dos estados emocionais, cujo conjunto constitui a gama de todos os sentimentos humanos, do mais agradável ao mais insuportável (CHEMAMA, 1995, p. 10). Neste sentido, até se pode admitir a ideia de que família seja locus de afeto, jamais, porém, no sentido coloquial, em que afeto é sinônimo de amor, de carinho. Não é só amor e carinho o que se vê no ambiente familiar. Há de se tomar cuidado com esse modismo bem intencionado, mas meio infantil, principalmente nas adoçóes, mas não só nelas, por óbvio. Hoje em dia, por exemplo, com base nessa pieguice romântica, falase em indenização por abandono afetivo, o que não se justifica, por nenhum prisma, principalmente por ampliar a culpa, além da medida, nas relaçóes paterno-filiais (POLI, FIUZA, 2015).

Como anota Rodotà (1997, p. 5) a antiga virtude do direito privado ressurge exatamente no jogo entre regulaçáo e espontaneidade que ofereça grande espaço para as escolhas e autonomia individual. Assim, antes e acima de tudo, há de se respeitar a opção pessoal das pessoas, suas condições ou possibilidades, a liberdade individual de constituir a forma de relacionamento que melhor lhe aprouver, ou aquela que for possível ou estiver ao seu alcance. Lembrando-se sempre, com muita cautela, que existem razões individuais de diferentes matizes pelas quais as pessoas inserem-se em um núcleo familiar, enfim, a cada qual deve ser possibilitado o caminho escolhido ou o caminho possível. À sociedade e ao direito cabem apenas acompanhar essa trilha no sentido de oferecer a garantia fundamental de dignidade, de liberdade e de igualdade a tais indivíduos.

Certo é que o modelo tradicional de família constituída pelo casamento com filhos há anos não é majoritário nos cinquenta e sete milhões de lares do Brasil ${ }^{5}$. Molduras familiares de diferentes matizes (mães solteiras, pais que cuidam sozinhos de seus filhos, casamentos sem filhos, unióes homossexuais, dentre outras) representam a realidade de $56,1 \%$ dos domicílios brasileiros.

\footnotetext{
5 Enquanto $75 \%$ dos lares eram formados por casais com filhos em 1980, esse número caiu para 43,9\% em 2013. Atrás da opção pelo casamento tradicional aparecem os casais sem filhos (19,4\%) e os lares com muIheres solteiras com filhos (16,5\%). Dados de 2013 do Instituto Brasileiro de Geografia e Estatística (IBGE).
} 
Esse tipo de notícia gera cada vez mais polêmica. Se, por um lado, trata-se de reconhecer modelos familiares que ultrapassam os tradicionalmente aceitos, por outro não faltarão os que tentarão utilizar tais notícias para justificar sua oposição, argumentando a possibilidade de abertura à temida poligamia ou à banalização do que seria um núcleo familiar a merecer guarida jurídica. Assim, face ao espanto causado à parcela significativa da população e até mesmo aos juristas daquilo que consideram uma banalização das relaçóes afetivas e da parentalidade, há uma busca frenética que procura traçar elementos justificadores ou legitimadores da família a ser enaltecida pelo manto jurídico. Não há dúvidas, porém, que a sociedade se encontra diante de uma realidade emergente e, possivelmente, náo tâo marginal. Estaria o conceito de família, mais uma vez, ameaçado? E qual seria o seu alcance? Essas são algumas indagações que se colocam, mas que não serão frontalmente examinadas nesse trabalho, já que o objetivo proposto é analisar a suficiência ou não do afeto como elemento justificador da proteção jurídica conferida à família.

A conformação da família contemporânea em muito difere do modelo oitocentista: patrimonial, hierarquizada, patriarcal. O conceito atual de família perpassa pela convivência pautada na solidariedade em função dos laços conjuntos. A família deve ser encarada como a comunidade de vida material e quando possível afetiva entre seus integrantes, união de esforços para o desenvolvimento de atividades materiais e sociais, convivência que promove mútua companhia, apoio moral e psicológico, na busca do melhor desenvolvimento da personalidade dos indivíduos que a compóem.

Manusear álbuns de família é uma experiência reveladora: são registros de moda, de hábitos culinários, de brincadeiras, de formas de conduta, de postura, de costumes e, sobretudo, para um olhar um pouco mais arguto, de distinçóes hierárquicas.

Nas fotos mais antigas, nos antepassados mais remotos, distingue-se logo a figura do patriarca, centrado, sisudo, compenetrado que, em geral, se posta de pé cercado dos filhos, tendo ao seu lado os mais velhos e, ao fundo, ou cuidadosamente sentados e arrumados, os netos. A esposa e as demais mulheres buscam resguardar nos olhos o respeito, obediência e quase veneração à figura central a quem devem agradecer permanentemente a subsistência e a possiblidade de alcançarem a graça de serem mães.

Os homens preservam o olhar agudo, símbolo da responsabilidade pelo sustento material da família, as mulheres entre docilidade e submissão revelam uma vida dedicada às tarefas do lar e à educação dos filhos. As casadas, cumprido seu objetivo maior, podem dedicar-se à preparação das mais jovens: a busca por um casamento conveniente que lhes proporcione estabilidade e status social. Essa família, voltada à tradiçáo procriativa e às alianças para estreitar os laços biológicos ou favorecer o acúmulo patrimonial, é hierarquizada, monolítica, horizontal. Prescreve códigos de conduta, repudia as diferenças, mascara e esconde realidades.

Voltam-se esses indivíduos à proteção e salvaguarda da instituição. A família representada pelo casamento e pelos laços de sangue há de ser mantida. Sacrifícios, amores partidos, filhos bastardos abandonados, traições, tudo vale para se manter a unidade.

As fotos de família atuais causariam estranhamento a qualquer distinto cidadão do início do século passado. Vê-se uma mulher cercada por seus dois filhos, frutos de inseminação artificial, em outra foto, dois homens disfrutam de uma risada matinal à mesa do café da manhã, cercados por seus cães. Em um terceiro retrato, um casal divide a cena com dois adolescentes filhos de uma relação anterior e os dois bebês havidos há poucos meses antes da cerimônia de casamento. Há ainda fotos daqueles que decidiram viver em casas separadas, do casal que conheceu uma moça na praia e está com ela até hoje. Das amigas que se tornaram amantes, companheiras. 
Enfim, em poucos anos, considerando a história da humanidade, o panorama familiar descortinou-se. As mulheres alcançaram a tão almejada igualdade, obtiveram oportunidades de independência econômica, os filhos primogênitos perderam o protagonismo, a perenidade do casamento desapareceu, a família não é mais sinônimo de casamento.

Começa a mostrar a multiplicidade de arranjos familiares, o prestígio alcançado pelas crianças, seres até então sem voz, entregues aos cuidados das amas, cunhãs, isoladas do convívio dos adultos, passam a ter interesses tutelados, participam como protagonistas do núcleo familiar, desafiam autoridade, clamam por direitos, exigem participação. As configuraçóes familiares atuais denotam a riqueza da diversidade, rompem com tradiçóes morais, buscam a satisfação de desejos/necessidades, redefinem papéis e funções e pretendem satisfazer o afã por afeto. O termo família não mais simboliza a síntese de todas as convenções características de uma sociedade patriarcal.

A análise das fotos de família revela ainda, muito além dos inúmeros arranjos familiares possíveis, a ênfase conferida aos momentos de alegria e felicidade. Essa visão romanceada do núcleo familiar que se multiplica nas redes sociais é de certa forma capturada pelo direito de família. Esse movimento parece ter ganhado força na luta pelo reconhecimento das famílias homossexuais que foram carinhosamente cunhadas de unióes homoafetivas. Essa nomenclatura, que teve o mérito de abrandar o elo sexual entre os parceiros, trouxe a afetividade como novo parâmetro de valoração familiar, a justificar a proteção jurídica tão almejada por esses pares. Curioso notar que reconhecidamente o oposto da união homoafetiva continua ser a união heterossexual, como se, para merecer guarida jurídica, os casais homossexuais tivessem de apresentar um elemento afetivo como justificador da sua união. As últimas reformas do ordenamento jurídico, seja pela promulgação da Constituição da República de 1988 ou pelo Código Civil de 2002 que albergaram a figura da união estável, não exigiram o surgimento da heteroafetividade para qualificar esse tipo de relação.

A situação dos homossexuais é reveladora: atualmente na sociedade brasileira contemporânea homossexuais são convidados a participar da proteção jurídica quando demonstram que compõem uma família, família pautada no afeto. $\mathrm{O}$ ingresso na proteção familiar dos indivíduos homossexuais no ordenamento jurídico parece seguir o fluxo de um verdadeiro polimento moral. As velhas lutas contra formas de assujeitamento parecem produzir outros assujeitamentos, como já alertou Judith Butler (BUTLER, 2004). O caráter performativo do enunciado da homoafetividade (AUSTIN, 1975) acaba por gerar diametralmente o não-homoafetivo, reproduzindo hierarquias valorativas.

\section{Da subjetividade em massa à subjetividade emergente}

A importância desse estudo se revela na percepção de que as relações familiares que não enaltecem o afeto (no sentido romântico do tema) sofrem rechaço de parte considerável da população e também da comunidade acadêmica da área jurídica. Habituou-se ao toque fortemente reproduzido de comportamentos e modos de vida que elevam a busca ao refúgio familiar como locus onde o afeto há de imperar. Tal indica que os signos individuais têm sido insistentemente apagados. Esse fenômeno acaba por repercutir na construção da subjetividade ínsita a cada indivíduo, que insuflado incessantemente pela violência da força da comunicação em massa, perde a capacidade de filtragem, essencial à elaboração de uma subjetividade única, distintiva, especial a cada um. 
A subjetividade refere-se ao universo de ideias, significados e emoçóes moldado internamente pelo sujeito a partir de suas relaçóes sociais, de suas vivências e de sua constituição biológica. Revela-se ainda como locus de suas manifestaçóes afetivas e comportamentais. É o mundo interior, sujeito às influências e influxos constantes das experiências vivenciadas, da cultura, do modo de viver, das relaçóes sociais (BIRMAN, 2000, p. 45). Mas, por outra faceta, a subjetividade também se mostra automoldável, ou seja, o próprio indivíduo deve ser capaz, paralelamente às influências externas, de promover novas formas de subjetividade, recusando-se ao ajustamento imposto pela massificação das informaçóes, capaz de afugentar a possibilidade do afloramento de seus desejos íntimos, da formação de seu próprio e único juízo sobre as coisas e sobre seus sentimentos (CUNHA, 2002, p. 170).

$\mathrm{O}$ assujeitamento imposto pela massificação da informação e repetição acrítica de comportamentos conduz à perda da memória histórica individual, exclui e estigmatiza o diferente, condiciona a aceitação aos ditames do consumo, impede que a subjetividade se expresse de sua maneira mais peculiar que é a maneira de sentir, pensar, fantasiar, sonhar, amar e fazer de cada um (MOREIRA, 2009).

Por isso, a subjetividade é essencial à construção do destino de cada um e da própria coletividade (SARZ, 2009). Assim, não se alinha a padróes de produção, a moldes, a processos de captura e submissão, que tendem a mobilizar o indivíduo a pensar, agir e até mesmo sentir.

A subjetividade emergirá na escolha da forma de família, na qual o indivíduo se sinta acolhido, portanto, como elemento único e característico de cada um e revelará uma multiplicidade de espectros familiares. A união familiar não essencialmente fulcrada no afeto romantizado, de certa forma, espelha o oposto da subjetividade fabricada, enlatada, disponível para ser consumida, produzida em massa, fruto de um discurso que remete a enunciados de poder, que não permite individualizaçóes e processos próprios de "fantasmização".

A eleição de um núcleo familiar que escapa aos tradicionais padróes de afeto encampados e reproduzidos pelo universo jurídico corresponde, nessa linha, à consolidação de processos conducentes à emancipação ${ }^{6}$, à perseguição da expressão de uma identidade cultural e psíquica própria de cada um, que se revela pelo reconhecimento do inconsciente, da clivagem subjetiva. Dessa forma, a família há de ser vista não como uma massa heterogênea, um aglomerado, uma soma de individualidades aleatórias e não situadas, mas sim como um conjunto aberto, uma coleção de singularidades, em que cada membro é tomado em suas peculiaridades, um campo discursivo fértil em que se encadernam incontáveis significantes. Assim, no seio da família, aflora-se a constituição subjetiva que implica, de certa forma, uma realização de um desejo (LACAN, 1998, p. 56). E esse desejo poderá se revelar e tomar inúmeras e inusitadas feições.

Não há como negar que o homem contemporâneo deve iniciar uma jornada de reflexóes e questionamentos de forma a reconquistar estruturas que possibilitem o pleno desenvolvimento da personalidade e da subjetividade de cada um. Há de se desvencilhar de tentativas de uniformização, independentemente de quem as impóe: o Estado, o consumismo, o modismo ou a religião.

Apesar de a racionalidade ser uma característica essencial da natureza humana, que impulsiona ações individuais e sociais, compõe-se de significados diversos, sutis e implícitos, que influenciam e direcionam a visão de mundo da sociedade. A racionalidade emancipatória direciona-se pela capacidade de homens e mulheres deliberarem sobre as condições da sua própria existência opõe-se à racionalidade instrumental ou funcional, chamada por Santos (2000, p. 123) de indolente (leva em consideração o cálculo utilitário de consequências como única referência a guiar as ações dos indivíduos que adquirem um sentido de comportamento racional limitado).
} 
Requer-se uma mudança de estado, já que os pilares da sociedade contemporânea ainda repousam na uniformização, marca fundamental do estado moderno, que nega sistematicamente a diversidade e outras formas de enxergar o mundo. Vive-se um momento de mudança de época e de crise das instituiçóes modernas. Há quem ainda procura ocultar a diversidade para estabelecer-se um padrão, um arquétipo que se opera por um encobrimento de outras formas de pensar e compreender o mundo, na tentativa de fixar-se uma hegemonia filosófica e ideológica. A imposição da hegemonia abafa os costumes locais e encobre as diversidades sob um falso manto de proteção (museificação).

Por essa razão, as discussóes que giram em torno do afeto, erigido como elemento norteador de todas as relaçóes familiares, contribuem para que no futuro exista o devido reconhecimento e consolidação de subjetividades, modos de vida e famílias diversas. O Direito deve se integrar por um processo de constituição contínua e dialética marcado pelas dimensóes das realidades múltiplas (MOREIRA PINTO, 2004, p. 87).

Considerando a análise de Butler (2004) que nos alerta para as capturas identitárias, e adaptando-as ao contexto brasileiro, seria possível afirmar que a apropriação do afeto romântico pelo direito de família reduz as possibilidades discursivas que induziriam a outras justificativas menos aprisionadoras do que seria um núcleo familiar. $\mathrm{O}$ foco das discussóes jurídicas centradas em elementos de gênero, como ocorre tradicionalmente no direito brasileiro, como por exemplo, para caracterizar o casamento, parecem ter se deslocado para a imposição de uma família afetiva o que não contribui para a flexibilização das estruturas jurídicas que permitiriam o reconhecimento amplo da pluralidade familiar.

Faz-se necessária a articulação de justificativas de caráter mais geral e dinâmico que permita a qualquer indivíduo, a despeito de suas escolhas sexuais, sentimentais ou quaisquer que sejam, a proteção do núcleo familiar não impondo formas predeterminadas de se relacionar. A comunidade familiar, muito além das figuras do casamento e da união estável, podem assumir incontáveis contornos e hão de se fundar em outros elementos como a solidariedade, o companheirismo e a cooperação, elementos muitas vezes mais fortes e contundentes do que os laços de sentimentos românticos e efêmeros.

A apropriação do afeto como justificativa de proteção do núcleo familiar, em detrimento a outras de caráter mais universal, aponta para um risco ameaçador: qualquer pessoa que, por razóes próprias, que não interessem ao universo jurídico, não partilhe desses preceitos impostos pelo amor, não estaria propensa a reconhecer o direito de união como algo válido de modo irrestrito. Nesse contexto, o amor mostra-se como uma justificativa frágil e fragmentadora. Perceba-se a forma como é defendido o reconhecimento jurídico no "direito homoafetivo": "entendo que o afeto enquanto elemento psíquico também deve ser valorizado como princípio jurídico porque em muitos casos é possível comprová-lo (por testemunhas, por exemplo)" (VECCHIATTI, 2013, p. 203).

Analisando a República Velha, Sérgio Buarque de Holanda (HOLANDA, 2012, p. 55) afirma que "o desconhecimento de qualquer forma de convívio que não seja ditada por uma ética de fundo emotivo representa um aspecto da vida brasileira que raros estrangeiros chegam a penetrar com facilidade". Resta claro da leitura desse extrato que há muito a cultura brasileira apresenta dificuldades para utilizar um discurso impessoal que permita a ruptura com padróes particulares, como aqueles baseados nos afetos. O alerta de Holanda permite avaliar como contra os valores afetivos incidem sobre as instituiçóes públicas "A mobilização em torno dos afetos reflete assim um problema político que ignora os riscos decorrentes da relativização das diferenças que separam a cena particular do mundo público.” (VECCHIATTI, 2013, p. 203). 
Deve ficar claro que a crítica ora proposta não recai na legitimidade das relaçóes familiares baseadas no amor romântico, a presença do amor é salutar e desejável nas situaçóes relacionais. $\mathrm{O}$ alerta que se instaura refere-se à noção perpetuada pelo discurso jurídico de que esse é um elemento justificador da proteção familiar. Elevar o afeto como elemento essencial na formação e continuidade do núcleo familiar não é matéria pertinente ao direito a quem não caberia moldar a forma de convivência familiar. Elucidativa a advertência de Arendt (1962) que, em resposta a um texto publicado por James Baldwin, adverte-nos "na política, o amor é um estranho, e quando nela se intromete nada pode ser alcançado exceto hipocrisia” ${ }^{53}$. A mensagem da autora parece clara: sob o pretexto do amor, corremos o risco de despolitizar o debate, restringindo-o a modos de viver que estáo longe de ser universais. Em outro momento, ao analisar o debate acerca do casamento interracial nos Estados Unidos, reflete:

A segregação é a discriminação imposta pela lei, e a dessegregação não pode fazer mais do que abolir as leis que impóem a discriminação; não pode abolir a discriminação e forçar a igualdade sobre a sociedade, mas pode e na verdade deve impor a igualdade dentro do corpo político. Pois a igualdade não só tem a sua origem no corpo político; a sua validade é claramente restrita à esfera política. Apenas nesse âmbito somos todos iguais (ARENDT, 2004, p. 272).

Há de se reconhecer o direito de toda pessoa de viver e desenvolver-se no seio de uma estrutura familiar. O desenvolvimento pleno da personalidade e a formação da subjetividade dependem em grande medida da inserção familiar. Portanto, a família, quaisquer que sejam as feiçóes que assume, merece ampla proteção de forma efetiva e concreta. Desta maneira, qualquer Estado que considere os direitos humanos em sua configuração não pode subtrair a proteção às diversas concepçóes de família que se apresentam, sob pena de violar diretamente o ser humano.

\section{Família: núcleo de cooperação}

A função da família que se pretende desenhar ultrapassa o âmbito das relaçóes domésticas/patrimoniais quando assume o caráter de patrocinar a realização da cidadania e da promoção da dignidade de seus membros e, como tal, não comportaria hierarquização, mas sim cooperação mútua, na medida da capacidade de cada um de seus membros.

A família, independentemente do arranjo que possa assumir, é o espaço indispensável para a garantia do desenvolvimento digno da pessoa humana e a proteção de seus membros se dará, em primeira instância, pelo respeito à autonomia de cada um. A família atual transcendeu uma concepção eudemonista, na qual se busca exclusivamente a felicidade individual (TEIXEIRA, 2007, p. 37) fulcrada apenas no afeto, para uma concepção mais solidarista, como núcleo de cooperação. A família hoje é essencialmente dinâmica, voltada não apenas à satisfação dos interesses ou necessidades individuais de

\footnotetext{
$7 \quad$ James Baldwin (1924-1987) foi um americano militante pelos direitos raciais e sexuais que acreditava que o amor seria o motor das revoluções sociais. Esta carta de Hannah Arendt é uma resposta ao ensaio Letter from a Region of My Mind, publicado em 17 novembro de 1962, na revista The New Yorker.
} 
seus membros, mas direciona-se sobretudo à realização do pleno desenvolvimento da personalidade de seus integrantes.

O conceito atual de família perpassa pela convivência pautada na solidariedade e cooperação. A família deve ser encarada como a comunidade de vida, união de esforços para o desenvolvimento de atividades materiais e sociais, convivência que promove mútua companhia, apoio moral e psicológico, na busca do melhor desenvolvimento da personalidade dos indivíduos que a compóem. Em todos os lares onde houver pessoas ligadas seja por laços de sangue ou não, mas unidas pelo plano de concretização das aspiraçóes de cada uma delas e daquele núcleo como um todo, concatenadas e organizadas econômico e psicologicamente, haverá uma família.

Nesse trabalho, conceituamos a família como agrupamento de pessoas comprometida em uma união estável, voluntária e cooperativa que cumpre a funçâo de promover e proteger seus integrantes, um organismo solidário. Família não apenas como elemento dado pelo legislador, mas revelada também pela observação social dos fatos nas relaçóes intersubjetivas. Busca-se um horizonte familiar que revalorize e veicule a solidariedade, a compreensão e, sobretudo um espaço saudável para o livre desenvolvimento da personalidade e a construção da plena autonomia das crianças e adolescentes.

Há assim de se buscar privilegiar a expressão da liberdade no seio da família reconhecendo aos seus integrantes a possibilidade de determinar a forma de constituição e direção da vida familiar, possibilitando-lhes a interpretação das exigências de cada qual na busca do objetivo comum deste núcleo solidário e cooperativo, bem como da busca das aspirações individuais. As estipulaçóes recíprocas assim podem assumir papel "de regra e instrumento de realização do princípio da igualdade moral e jurídica, e ao mesmo tempo relativamemente à natureza $\mathrm{e}$ aos conteúdos da direção fixada” (PERLINGIERI, 2002, p. 302).

Dessa maneira compreendido, há de se admitir o caráter dinâmico da família, a possibilitar-lhe inúmeras e inusitadas feiçóes, e, por consequência, não se pode negar que a norma jurídica familiar deverá assumir também contornos dinâmicos, sob pena de regrar o vazio, afinal submete-se a família a constantes movimentos sociais, históricos, valorativos a importar diuturnas mutaçóes.

A família sustentará sua função promocional se unida pelos elos de cooperação e solidariedade. A família no modelo democrático deve ser reconhecida e protegida pela comunhão de vida que encerra. Comunhão econômica, afetiva em sentido amplo, de entrega, de disposição, de cuidado e respeito mútuo, de distribuição de tarefas, de solidariedade entre seus membros e sobretudo de respeito às escolhas individuais, às individualidades.

De toda sorte, entende-se que a família deve ser encarada como a comunidade de vida entre seus integrantes, união de esforços para o desenvolvimento de atividades materiais, sociais e existenciais, convivência participativa que promove mútua companhia, recíproco e complementar apoio moral e psicológico, na busca do melhor desenvolvimento pessoal de seus membros, garantindo, assim, autodeterminação e a realização de cada um.

$\mathrm{O}$ enunciado do afeto apropriado pelo discurso jurídico que evoca o amor romântico como modo de legitimação de direitos é sedutor e perigoso. Ignora que as identidades são fruto de enunciados produzidos e oferecidos por determinada cultura. Vale a lição de Foucault sobre as formas de reconhecimento e seu aprisionamento potencial:

Essa forma de poder que se exerce sobre a vida cotidiana imediata, que classifica os indivíduos em categorias, que os designa por sua individualidade própria, que os ata à sua identidade, os impóe uma lei (regime) de verdade que deve ser reconhecida 
por eles e que os outros devem reconhecer neles [...] um sujeito atado a sua própria identidade pela consciência e conhecimento de si. (FOUCAULT, 1994c, p. 227).

Há de se reconhecer uma série de relações íntimas que podem ou não se assentar na retórica do amor. O próprio conceito de família utilizado na psicologia contemporânea revela-se mais abrangente, ultrapassando o modelo sustentado em relaçóes de parentesco, coabitação ou afetividade: "Uma família é um sistema que opera através de padróes transacionais, isto é, de regras oriundas das interaçôes repetidas entre os indivíduos" (MINUCHIN, 1982, p. 57).

Certo é que a família é um núcleo do qual todos parecem querer participar. Assim, as unióes familiares, longe de seus ornamentos únicos da sacralidade, são mais que nunca eletivas, por vezes fruto de um amadurecimento reflexivo, fulcradas em laços de afeto ou apenas em vínculos que atendem a critérios de utilidade ou conveniência. Pouco importa! Resta ao Direito garantir de modo igualitário cada escolha, cada construção, cada núcleo, ainda que aos olhos dos mais desconfiados pareçam bizarros ou inadequados.

\section{Conclusão}

O afeto, na sua acepção romântica, na seara jurídica institucionalizou-se capturado como estratégia de controle do que é ou não entidade familiar, de tal forma que promove a cristalização de territórios existenciais, espécie de coágulo do tecido familiar. $\mathrm{O}$ uso repetido do afeto (sem qualquer discursividade crítica quanto ao seu conteúdo) passou a referendar determinado modo desejado de vida; formas de relação paterno-filial, laços de conjugalidade, e até própria constituição do enlace paterno-filial (a denominada relação sócio-afetiva).

Ora, é inegável a fissura no discurso jurídico que sustenta o afeto em uma concepção única. Esse modelo, embora apresentado como monolítico e inquebrantável, revela-se falacioso. Realidades familiares pautadas ou não pelo afeto na concepção ora criticada merecem guarida jurídica. É hora de virem à tona todos os núcleos familiares, sejam estes ou não inebriados pelo tom confortável do afeto romântico. Experiências familiares refletem a complexidade da vida social e aquelas até então ofuscadas, escondidas, marginalizadas, por não refletirem a dose desejada de afeto devem emergir do anonimato. É hora de o Direito se verter mais uma vez à força social. Há de desconstruir os lugares de não Direito, refutar a externalidade da situação de sujeito de direito dos indivíduos nas salientes demarcaçóes e contornos atuais da conjugalidade e até da relaçâo paterno-filial. O Direito deve mergulhar em águas turbulentas, enveredar-se por caminhos não tão bem torneados, abandonar o flúmen tranquilo de cogniçóes já consolidadas.

É hora de abandonar o percurso conformista da humanidade, o desejo ao processo estratificante das instituições, a âncora invisível, o conforto arrimo do instituído, que reproduz sempre o mesmo, como se fosse único o modo de coexistência: "Mil caminhos existem que ainda não foram palmilhados, anunciou Zaratustra. Mil saúdes e ocultas ilhas da vida. Ainda não esgotados nem descobertos continuam o homem e a terra dos homens" (NIETZSCHE, 1996, p. 91).

O fato é que diversas e incontáveis realidades coexistem e deve-se pensar no caso concreto, nas peculiaridades de cada núcleo familiar, analisando os diversos elementos de cada uma destas relaçóes familiares e considerando que, aos olhos da Constituição da 
República de 1988, o que importa é formação em si de um duradouro núcleo doméstico pautado na solidariedade e cooperação. O sistema jurídico há de ser visto como um organismo social e dinâmico, suficientemente aberto e amadurecido, que, reconhecendo a sua incompletude, acolhe os problemas que se renovam sem prejuízo de sua ordenação sistemática, orientando-se à consagração dos princípios constitucionais, e seus reflexos sobre a ordem civilística.

A busca por igualdade de direitos, por liberdades e pela consagração do pluralismo familiar não deve institucionalizar subjetividades e elevar o afeto romântico como signo de modelo universal na conformação familiar.

Para o efetivo reconhecimento jurídico e social da multiplicidade de formas de família existentes, deve se desconectar de quaisquer imperativos enclausurantes, sejam aqueles tradicionais, erigidos na composição binária homem e mulher ou ainda em novos imperativos como o afeto. A justificativa para a ampliação de direitos e prerrogativas às unióes familiares deve assentar-se nos direitos fundamentais (liberdade, igualdade, não discriminação), de forma a garantir que a esfera pública abrace de forma laica e abstrata os interesses de todos os indivíduos que se unem por quaisquer laços, inclusive àqueles que escapam a convençóes seculares ou a pressupostos valorativos.

\section{REFERÊNCIAS}

ARENDT, Hannah. The Meaning of Love in Politics. A Letter by Hannah Arendt to James Baldwin. 1962. Disponível em: http://hannaharendt.net/documents/baldwinII. html. Acesso em: 12 maio 2016.

"Reflexóes sobre Little Rock". In: ARENDT, Hannah. Tradução de Rosaura Einchenberg. São Paulo: Cia das Letras, 2004. p. 160-281.

AUSTIN, John. How to Do Things with Words. Cambridge: Harvard University Press, 1975.

BAUMAN, Zygmunt, Vida para consumo: a transformação das pessoas em mercadorias. Tradução: Carlos Alberto Medeiros. Rio de Janeiro: Jorge Zahar, 2008, 190p.

BIRMAN, Joel. Entre cuidado e saber de si - sobre Foucault e a psicanálise. Rio de Janeiro: Relume-Dumará, 2000.

BUTLER, Judith. “Is Kinship Always Already Heterosexual?” In: ARENDT, Hannah. Undoing Gender. New York, Routledge, 2004. p. 102-130.

CAMARGO, Margarida Maria Lacombe. Hermenêutica e Argumentaçáo: uma contribuição ao estudo do Direito. 2. ed. Rio de Janeiro: Renovar, 2001.

CHEMAMA, Roland. Dicionário de psicanálise. Porto Alegre: Artes Médicas Sul, 1995.

CUNHA, Eduardo L. Entre o assujeitamento e a afirmação de si. Cadernos de Psicanálise, SPCRJ, v.18, n.21, p.167-180, 2002.

DIAS, Maria Berenice. Uniáo homossexual: o preconceito e a justiça. 5. ed. Porto Alegre: Livraria do Advogado, 2011.

FOUCAULT, Michel. A verdade e as formas jurídicas. Rio de Janeiro: PUC, 1974.

. A ordem do discurso. Tradução de Laura de Almeida Sampaio. São Paulo: Edições Loyola, 2001. 
. "Entretien avec Michel Foucault". In: DEFERT, Daniel; EWALD, François (Ed.). Dits et ecrits, v. III. Paris: Gallimard,1994b. p. 140-160.

. "L'éthique du souci de soi comme pratique de la liberté". In: DEFERT, Daniel; e EWALD, François (Ed.) Dits et ecrits,v. IV. Paris: Gallimard, 1994c. p. 222-243.

HOLANDA, Sérgio Buarque de. O homem cordial. Sáo Paulo: Penguin Classics/ Companhia das Letras, 2012.

LACAN, Jacques. Os complexos familiares na formação do indivíduo. Tradução de Marco Antônio Coutinho Jorge e Potiguara Mendes da Silveira Júnior. Rio de Janeiro: Jorge Zahar Editor, 2002.

MINUCHIN, Salvador. Famílias: funcionamento e tratamento. Porto Alegre: Artes Médicas, 1982.

MOREIRA, Jacqueline de Oliveira. Mídia, espetáculo e sociedade de consumo. In: CRP-04 (org.), Subjetividade(s) e sociedade: contribuiçóes da Psicologia. Belo Horizonte: Casa do Psicólogo, 2009, p. 89-102.

MOREIRA PINTO, João Batista. As diferentes concepçóes do sujeito e suas inter-relaçóes com o direito. Revista Veredas do Direito. v.1, n.2, p. 81-90, Belo Horizonte, 2004.

NIETZSCHE, Friedrich. Assim falou Zaratustra. Martin Claret - Coleção Obra Prima: São Paulo, 1996.

PERLINGIERI, Pietro. Perfis do direito civil: introdução ao direito civil constitucional. Tradução Maria Cristina de Cicco. 2. ed. Rio de Janeiro: Renovar, 2002.

POLI, L. C. Famílias simultâneas: uma realidade invisível?. Direitos Fundamentais \& Justiça, v. 31, p. 56-79, 2015.

POLI, L. C.; FIUZA, César. Nova ordem familiar: desafios de uma abordagem jurídicopscanalítica. Direito de Família e Sucessôes. 1ed.Florianópolis: CONPEDI, 2015, v. 1, p. 169-193

POLI, L. C.; FIUZA, C. A. C. . Famílias: Múltiplas dimensões e reconhecimento. O DIreito entre a Esfera Pública e Autonomia Privada. 1ed.Belo Horizonte: Fórum, 2015, v. 1, p. 53-71

RODOTÀ, Stefano. Lo specchio di Stendhal: Riflessioni sulla riflessioni dei privatisti. Rivista Critica del Diritto Privato, Napoli: Jovene, 1997.

SARZ, Luiz Alberto. Mídia e produçáo de subjetividades: questôes da cultura. In: Mídia e psicologia: produção de subjetividade e coletividade. O bárbaro frente ao espelho. Brasília: Conselho Federal de Psicologia, 2009. p. 91-98.

SUPREMO TRIBUNAL FEDERAL. Julgamento em conjunto da ADI 4227 / DF e da ADPF 132 / RJ - Rel. Min. Ayres Britto, DJe 14.10.2011. 2011. Disponível em: http://redir.stf.jus.br/ paginadorpub/paginador.jsp?docTP=AC\&docID=6286 35 . Acesso em: 22 mar. 2016.

TEIXEIRA, Ana Carolina Brochado. A disciplina jurídica da autoridade parental no direito civil contemporâneo. 2004. Dissertação - Faculdade Mineira de Direito da PUC-Minas, Belo Horizonte.

\section{Luciana Poli}

Pós doutora em Direito pela UNESP(bolsista Capes) Doutora em Direito pela PUCMINAS. Professora na PUCMINAS 